\title{
Agroforestry, Horticulture, and the Evolution of Cropping Systems
}

\author{
Kenneth R. Tourjee \\ Center for Agroforestry, University of Missouri-Columbia, Columbia, MO 65211-7270 \\ John M. Shopland \\ Horticulture and Agroforestry Research Center, University of Missouri-Columbia, 10 Research Center Road, New \\ Franklin, MO 65274-9727 \\ Michele Warmund \\ Department of Horticulture, University of Missouri-Columbia, Columbia, MO 65211-7140
}

\begin{abstract}
The Association for Temperate Agroforestry defines agroforestry as an intensive land management system that optimizes the benefits from the biological interactions created when trees and/or shrubs are deliberately combined with crops and/or livestock (Slusher et al., 1997). Agroforestry is becoming increasingly important in the United States, and in other temperate regions of the world, as an attractive option for small landowners wishing to farm marginal land or manage forested tracts more intensively. The several research centers in the United States committed to agroforestry research are one measure of its importance. These include the Univ. of Missouri Center for Agroforestry (Columbia), the U.S. Dept. of Agriculture (USDA)-Agricultural Research Service Dale Bumpers Small Farms Research Center (Booneville, Ark.), and the USDAForest Service National Agroforestry Center (Lincoln, Nebr.).

The objective of this paper is to relate temperate agroforestry to horticulture in terms

Understanding this relationship requires examining the roles of silviculture and horticulture in agriculture.

\section{AGRICULTURE}

Agriculture has been broadly defined as the technology of raising plants and animals (Janick, 1986). Janick (1986) defined horticulture as that part of plant agriculture concerned with so-called garden crops, agronomy with field crops, and forestry with forest trees and their products. The species and commodity of interest determine classification into one of these three areas. The distinguishing characteristics of each area are derived from their respective commodities. These characteristics are determined by species biology and the cultural practices used in commodity production, and therefore suggest a forestry : agriculture dichotomy (Spedding, 1988). This dichotomy is best discussed in terms of ecological and genetic systems.
\end{abstract} of cropping systems evolution. We view this evolution as a movement from natural forest ecosystems toward agroecosystems. Agroforestry is a blending of its constituent (agriculture and forestry) characteristics (see, e.g., Fig. 2.1 in Nair, 1993). Therefore, these characteristics should be observable in each of the five temperate agroforestry systems-alley cropping (Garrett and McGraw, 1999), forest farming (Hill and Buck, 1999), riparian buffer strips (Schultzet al., 1999), silvopastures (Clason et al., 1999), and windbreaks (Brandle et al., 1999). Consequently, both horticultural (i.e., agricultural) and silvicultural research are required to develop productive and sustainable agroforestry cropping systems. However, the expertise exists within horticulture to study the interaction between trees and other crops (e.g., Hogue and Neilson, 1987). Therefore, the relationship between silviculture and horticulture in agroforestry is not necessarily demarcated along expertise in managing the productivity of woody vs. nonwoody plants.

Received for publication 13 Apr. 1998. Accepted for publication 26 Aug. 1998. We gratefully acknowledge the editorial assistance of Lyn Mortimer. The cost of publishing this paper was defrayed in part by the payment of page charges. Under postal regulations, this paper therefore must be hereby marked advertisement solely to indicate this fact.

\section{ECOLOGICAL PERSPECTIVE}

An ecological perspective on the differences between forest and agricultural systems focuses attention on management decisions. Key management practices of horticulturists and agronomists (fertilization, irrigation, pesticide/herbicide treatment, and tillage) are more intensive than those of foresters (pruning, seeding/planting, and thinning). Moreover, agroecosystems are manipulated to a much greater extent than forest ecosystems. Traditionally, agricultural science attempts to maximize productivity, often with intensive inputs of labor and resources, by creating 'domesticated environments' [environments modified to suit the purposes of a grower-e.g., greenhouse rose (Rosa sp.) production]. Today, however, there is great interest in developing and using agricultural methods that are less intensive [e.g., no-till soybean (Glycine max L.) production]. Silviculture, on the other hand, has been developed to manage natural woodlands for optimal production, although current trends are toward a greater reliance on intensive plantation forestry.

\section{GENETIC PERSPECTIVE}

A genetic perspective on the differences between forests and agroecosystems focuses attention on genetic diversity and plant domestication. The genetic diversity of horticultural and agronomic crops is usually defined in terms of genotypes or highly selected populations. Forestry generally defines genetic diversity at the species and provenance levels; a forest stand of even a single species usually contains much more genetic diversity than does the typical orchard. We can infer from this that forestry and horticulture/agronomy operate at opposite ends of the domestication scale, since domestication is an evolutionary process driven by selection. Oak (Quercus sp. L.) timber, pecan [Carya illinoinensis (Wangenh.) K.] nuts, and apple (Malus $\times$ domestica Borkh.) fruit are three commodities that show this relationship between domestication and agricultural status. Oaks are relatively unselected and are under the purview of forestry. Apples have a long history of crop evolution and are clearly a horticultural crop. Pecan represents a transitional stage between these two domestication endpoints. Currently, horticulturists are developing intensive management practices and selecting pecan cultivars, although wild germplasm is still an important contributor to crop production(William Reid, personal communication).

\section{AGROFORESTRY}

Agroforestry's identity relies less on specific commodities and more on how these endproducts are produced than does the identity of either horticulture or forestry (Anderson and Sinclair, 1993). Consequently, its definition must reflect a commodity-free but disciplinecentered approach. Alley cropping can serve as a model for examining the nature of agroforestry. Based on the preceding discussion, the extent to which ecological principles are applied to reduce the need for external inputs, and how much domestication is expressed by the germplasm, determines whether an alley cropping system is identified as agroforestry. From this perspective, intercropping hybrid corn (Zea mays L.) between rows of an almond [Prunus dulcis (Mill.) D.A. Webb] cultivar is not agroforestry-although it may be a profitable agricultural intercropping system. Both corn and almond grown in monoculture are agricultural crops selected from elite germplasm pools and their cultivation requires a high level of inputs. Intercropping them does not introduce a forestry com- 
ponent to the system from either an ecological or genetic perspective.

Agroforestry cropping systems occupy an intermediate position, between natural and agroecosystems, on a scale measuring domestication of the production environment. This is a result of blending agriculture with forestry. These systems should be designed to mimic at least some processes of natural forest ecosystems to obtain benefits that must otherwise accrue to the system externally. Woodmansee (1984) compared natural with agricultural ecosystems, and concluded that natural ecosystems have developed several mechanisms to sustain productivity that could be exploited in properly designed agricultural systems. The vegetative canopies and litter of natural ecosystems reduce soil temperatures during the season of most biotic activity, thereby reducing the rates of microbial activity and water evaporation. Decreasing the evaporation rate prolongs soil water availability. The lower soil temperatures also decrease rates of decomposition and mineralization. The net effect of these processes is to synchronize plant and microbial activity and reduce gaseous and leaching losses from excess mineralization. Another feature of natural ecosystems is that a large part of their nutrient content is retained within living tissues. Nutrients immobilized in living biomass are not vulnerable to erosion and leaching loss. Furthermore, Woodmansee noted that the rooting structure of natural ecosystems displays greater heterogeneity than does that found in typical agricultural systems, thus reducing the potential for nutrient loss through leaching.

Agroforestry research focuses on accelerating domestication through the development of advanced germplasm, cultural practices, and orchard design to exploit these ecological mechanisms of natural ecosystems. Domestication is directed toward the development of cropping systems that draw on the diversity inherent in a forest environment to create an agroecosystem with a reduced need for external energy inputs. Therefore, ecological considerations (i.e., understanding the relationships among component crops of the system), as well as the cash value of the companion crop, are critical aspects in system design. These relationships include enhancing pest management, minimizing energy inputs, checking soil erosion, and increasing the benefits of mutualism (e.g., through nitrogen fixation, mycorrhizal compatibility, shading, etc.). Also, the effects of allelopathy and competition for light, moisture, and nutrients must be gauged.

\section{HORTICULTURE}

Cropping systems research developed through agroforestry becomes increasingly horticultural as the system evolves, since agroforestry defined in this way is an intermediate stage in the domestication process. As the cropping system becomes more widely adopted, the economic aspect of the system increasingly dominates. Markets are established and competition among farms result in a selection for improved production efficiency. Harvesting agricultural products (outputs) from a system requires that inputs be increased. This is a distinguishing feature in comparing natural with agroecosystems. Further fine tuning the management of these cropping systems will increasingly depend upon improving the efficiency of input use-a horticultural more than a silvicultural research theme. However, cropping systems derived from agroforestry will remain different from those developed from a strictly agricultural standpoint. This is because the forestry component of agroforestry ensures that all of the implications of the question "Does a hectare of cropland equal a hectare of wild host plant?" are addressed as they relate to cropping system design (Janzen, 1986). These include the ecological mechanisms described by Woodmansee (1984) and the benefits obtained from the support a diverse plant community provides to predator insect populations. Altieri (1991) provides examples demonstrating the use of biodiversity in agroecosystems to control pest populations.

An evolution toward horticultural research is evident also from a genetic viewpoint. For example, black walnut (Juglans nigra L.) is a forest species widely used in alley cropping in the Midwest and parts of Canada. In the future, black walnut cultivars will bear little resemblance to their wild relatives. Nut and timber production and quality will greatly exceed that found in native forest trees. The ultimate development of the cropping system will rely on horticultural research in the sense that its germplasm will be highly selected and further genetic gains generally will be made without recourse to wild germplasm. Also, genotypes will be selected to interact positively with specific cultural practices.

\section{CROPPING SYSTEMS}

We define agroforestry cropping systems through the tension between forestry's approach to mix naturally compatible indigenous species with horticulture's charge to manipulate the environment for maximum productivity of perhaps disparate and exotic species. Intercropping blueberry (Vaccinum sp. L.) and ginseng (Panax quinquefolium L.) with pine (Pinus sp. L.) is an example of an alley cropping system that emphasizes the use of ecological principles in its design. Wild blueberry and ginseng both evolved in a woodland environment as understory plants exploiting niches different from those of their companion overstory trees. Potential commodities from this system are blueberries, ginseng botanicals, pine straw, and timber. Pine straw litter functions as acidic mulch (blueberry thrives on acidic soils) that improves soil structure. The trees provide a shade environment conducive to ginseng production. Optimization of this cropping system's efficiency would depend on research that is both horticultural and silvicultural. Designing the orchard to maximize the opportunity for light interception by the blueberry bushes while maintaining productivity from the other components would draw on horticultural concepts. Identifying sources (provenances) of ginseng germplasm compatible with pine stands and developing cultural methods to produce high-grade timber directly employ forestry concepts. 'Silvi/horticulturists' would maximize the efficiency of management operations for the alley cropping system. Agroforestry breeders would develop blueberry cultivars with increased shade tolerance, ginseng cultivars with increased tolerance to acidity, and pine cultivars that produce quality wood and pine straw with growth characteristics responsive to the intercropping environment.

Alley cropping hay between rows of black walnut trees grown for nut production is an example that shows the role of germplasm domestication in defining agroforestry. Black walnut is a heterozygous forest tree found in heterogeneous populations. It is in the early stages of domestication and horticulturists have not yet defined advanced cultural practices. Breeding for improved cultivars would rely heavily upon the concept of provenance. Selection against unwanted variation (e.g., variability in time to nut maturity) would probably be as important as improving mean performance. Therefore, breeding programs for black walnut would be similar to Duvik's prebreeding scheme for domestication of wild germplasm (Duvik, 1990). He proposed that prebreeding programs should be established to make the wild germplasm of established crops more accessible and useful to breeders.

Cropping systems coevolve with their germplasm because crop genotypes are selected to respond to specific cultural practices. The development of the mechanically harvested tomato is an excellent example of this process (Dickman, 1978). Once a cropping system is developed and established on a wide scale, market forces maintain it, and large fluctuations of the cropping system will be curtailed. The development of agroforestry practices, therefore, is more likely to begin with wild germplasm without well-defined cultural practices. Simply interplanting cultivars of a woody agricultural crop with those of another agricultural crop should not be considered agroforestry because this ignores the coevolution of crops and cultural practices within cropping systems. It is unlikely to result in optimal productivity for either crop without management practices designed to enhance beneficial interactions between system components (van Noordwijk, 1996).

\section{CONCLUSIONS}

Agroforestry cropping systems are modeled after forest ecosystems and agroforestry research has an ecological and genetic basis. These two disciplines relate agroforestry research topics to those of horticulture and silviculture. Ecology brings an emphasis on systems science and modeling. Genetics provides an understanding of genotype-by-genotype interaction and selection. Therefore, agroforestry research is constrained to a greater extent than is horticultural research, by those issues addressing development of cropping practices that emphasize minimum resource 
input while maintaining productivity. However, horticulturists have an important role to play in developing agroforestry cropping practices. Horticulture's focus on efficient crop management through appropriate resource input, combined with silviculture's emphasis on management of natural ecological processes, can make agroforestry systems more productive and profitable for the farmer. Using the strengths of each of these professions is much more efficient than approaching the problem of agroforestry design from a single front. The essence of agroforestry is not only the integration of trees with crops but, more importantly, the integration of the principles and practices of agricultural production science with those of forestry to produce a fully integrated treecrop system.

\section{Literature Cited}

Altieri, M.A. 1991. How best can we use biodiversity in agroecosystems? Outlook on Agr. 20:15-23.

Anderson, L.S. and F.S. Sinclair. 1993. Ecological interactions in agroforestry systems. Agroforestry Abstr. 6:57-91.

Brandle, J.R., L. Hodges, and B. Wright. 1999. Windbreaks. In: H.E. Garrett (ed.). North Ameri- can agroforestry: An integrated science and practice. Amer. Soc. Agron., Madison, Wis. (In press.)

Clason, T.R., S.H. Sharrow, and P.F. Folliet. 1999. Silvopastoral systems. In: H.E. Garrett (ed.). North American agroforestry: An integrated science and practice. Amer. Soc. Agron., Madison, Wis. (In press.)

Dickman, A.I. 1978. Interviews with persons involved in the development of the mechanical tomato harvester, the compatible processing tomato and the new agricultural systems that evolved. Shields Library, Oral History Office, Univ. of California, Davis.

Duvik, D.N. 1990. The romance of plant breeding and other myths, In: J.P. Gustafson (ed.). Gene manipulation of plants II. 19th Stadler Genet. Symp., Univ. of Missouri, Columbia. Plenum, N.Y.

Garrett, H.E. and R.L. McGraw. 1999. Alley cropping. In: H.E. Garrett (ed.). North American agroforestry: An integrated science and practice. Amer. Soc. Agron., Madison, Wis. (In press.)

Hill, D.B. and L.E. Buck. 1999. Forest farming. In: H.E. Garrett (ed.). North American agroforestry: An integrated science and practice. Amer. Soc. Agron. Madison, Wis. (In press.)

Hogue, E.J. and G.H. Neilson. 1987. Orchard floor vegetation management. Hort. Rev. 9:377-430.
Janick, J. 1986. Horticultural science. 4th ed. Freeman, New York.

Janzen, D.H. 1986. Does a hectare of cropland equal a hectare of wild host plant? Amer. Nat. 128:147149.

Nair, P.K.R. 1993. An introduction to agroforestry. Kluwer Academic Publ., Boston.

Schultz, D., J. Colletti, T.M. Isenhart, O.C. Marquez, W.W. Simpkins, J.M. Raich, and P.L. Schultz. 1999. Riparian buffer strips. In: H.E. Garrett (ed.). North American agroforestry: An integrated science and practice. Amer. Soc. Agron. Madison, Wis. (In press.)

Slusher, J.P., H.E. Garrett, and W.B. Kurtz. 1997. Agroforestry in Missouri. Forest Land Owner 56(2):52-56.

Spedding, C.R.W. 1988. An introduction to agricultural systems, 2nd ed. Elsevier, New York.

van Noordwijk, M. 1996. Mulch and shade model for optimal alley-cropping design depending on soil fertility, p. 51-72. In: C.K. Ong and P. Huxley (eds.). Tree-crop interactions: A physiological approach. CAB Intl., Wallingford, Oxon, U.K.

Woodmansee, R.G. 1984. Comparative nutrient cycles of natural and agricultural ecosystems: A step toward principles, p. 145-156. In: R. Lowrance, B.R. Stinner, and G.J. House (eds.). Agricultural ecosystems-Unifying concepts. Wiley, New York. 